\title{
EFEK JUS SEMANGKA TERHADAP JUMLAH DAN MOTILITAS SPERMATOZOA TIKUS WISTAR YANG DIPAPARI MSG
}

\author{
Tengku Muhammad Reza Syahputra, Muhammad Ichwan, Sufitni \\ Fakultas Kedokteran, Universitas Sumatera Utara, Indonesia \\ Email: rezasyahputra.tm@gmail.com
}

Diterima: November 2019, Diterbitkan: Desember 2019

\begin{abstract}
ABSTRAK
MSG merupakan asam glutamat digunakan sebagai penyedap makanan terutama dalam produk makanan olahan yang dapat melebihi kadar yang diperkirakan karena beberapa makanan tidak mencantumkan pada label kemasan. Beberapa penelitian melaporkan efek MSG pada berbagai organ terutama testis yang menyebabkan oligozoospermia dan morfologi sperma yang abnormal. Konsumsi MSG jangka panjang dan berlebihan menyebabkan kerusakan testis akibat stres oksidatif sehingga terjadinya peroksidasi lipid. Antioksidan pada buah semangka berperan mencegah kerusakan oksidatif. Tujuan penelitian ini adalah untuk mengetahui efek jus semangka terhadap jumlah dan motilitas sperma yang dipapari MSG. Penelitian ini merupakan penelitian kuantitatif eksperimental desain post test only control group, 35 ekor tikus Wistar jantan secara acak dibagi lima kelompok: KN(pellet), KP(MSG $10 \mathrm{mg} / \mathrm{grBB}), \mathrm{P} 1(\mathrm{MSG} 10 \mathrm{mg} / \mathrm{grBB}+$ jus semangka 25\%), P2(MSG 10mg/grBB + jus semangka 50\%), P3(MSG 10mg/grBB + jus semangka 100\%). Tikus diberi perlakuan selama 30 hari, kemudian dibunuh dan diambil vas deferens yang digunakan untuk pemeriksaan jumlah dan motilitas sperma. Uji statistik non parametrik menggunakan Mann-Whitney untuk mengetahui ada tidaknya pengaruh perlakuan. Hasil penelitian ini menunjukkan kelompok KP mengalami penurunan jumlah dan motilitas spermatozoa. Terdapat perbedaan yang bermakna pada jumlah $(\mathrm{p}=0,009)$ dan $\operatorname{motilitas}(\mathrm{p}=0,003)$ spermatozoa kelompok KP dibandingkan KN. Terdapat perbedaan bermakna pada motilitas kelompok $\mathrm{P} 3(\mathrm{p}=0,040)$ dibandingkan KP. Terdapat perbaikan motilitas pada kelompok P1, P2, dan P3 yang mendekati KN. Pemberian MSG menunjukkan hasil yang bermakna terhadap jumlah dan motilitas spermatozoa. Pemberian jus semangka dapat memperbaiki jumlah dan motilitas spermatozoa yang dipapari MSG.
\end{abstract}

Kata Kunci: Jus semangka, Jumlah dan motilitas spermatozoa, Monosodium glutamat.

\section{ABSTRACT}

MSG is a glutamic acid which is used as a main food flavoring in processed foods which can exceed the estimated levels because some foods do not put on the packaging label. Several studies have reported the effects of MSG on various organs, especially the testes which cause oligozoospermia and abnormal sperm morphology. Long-term and excessive consumption of MSG causes testicular damage due to oxidative stress resulting in lipid peroxidation. Antioxidants in watermelons play a role in preventing oxidative damage. This research aimed to find out the effect of watermelon juice on the number and motility of sperm exposed to MSG. This was quantitative experimental research design of post test only control group, 35 male Wistar rats were randomly divided into five groups: KN(pellet), KP(MSG 10mg/grBB), P1(MSG 10mg/grBB + watermelon juice 25\%), P2(MSG $10 \mathrm{mg} / \mathrm{grBB}+$ watermelon juice $50 \%), P 3(M S G 10 \mathrm{mg} / \mathrm{grBB}+$ watermelon juice $100 \%)$. Rats were treated for 30 days, then killed and taken vas deferens used to check sperm count and motility. The $K P$ group experienced a decrease in the number and motility of spermatozoa. There was a significant difference in the number $(p$ value $=0,009)$ and motility $(p$ value $=0,003)$ spermatozoa of the KP group 
compared to KN. There was a significant difference in the motility of the P3 group ( $p$ value $=0,040)$ compared to the KP. There was an improvement in motility in groups P1, P2, and P3 which approached $K N$. The administration of MSG showed significant results on the number and motility of spermatozoa. Giving watermelon juice can improve the number and motility of spermatozoa exposed to $M S G$.

Keywords: Watermelon juice, the number and motility of spermatozoa, monosodium glutamate.

\section{PENDAHULUAN}

Monosodium Glutamat (MSG) merupakan garam natrium dari asam glutamat yang terdiri dari $78 \%$ asam glutamat, $22 \%$ natrium dan air (Yonata $e t$ al., 2016). Asam glutamat adalah asam amino non-esensial yang berperan penting dalam metabolisme manusia dan merupakan salah satu asam amino yang banyak ditemukan di alam. Asam glutamat merupakan komponen utama dari banyak produk makanan tinggi protein dari hewan seperti daging, ikan, susu, dan keju, terdapat juga pada protein dari tanaman seperti jamur dan tomat (Ghosh, 2017; Sharma and Deshmukh, 2015; Tawfik and Al-Badr, 2012).

Monosodium Glutamat merupakan salah satu bahan aditif makanan yang paling banyak digunakan untuk menambah kenikmatan rasa makanan, terutama pada produk makanan olahan (Albrahim, 2018). Kandungan MSG dijumpai dalam keripik, agar-agar, mayones, kue, permen, roti, coklat, selai, burger, kentang goreng, pizza, mie dan di hampir setiap makanan yang disajikan di setiap restoran cepat saji (Abdel et al, 2018; Ghosh, 2017; Sharma and Deshmukh, 2015). Jumlah kandungan MSG dalam makanan dapat melebihi kadar yang diperkirakan oleh karena pada sebagian makanan olahan kadar MSG tidak dicantumkan pada label kemasan dan MSG juga seringkali tersembunyi dengan nama bahan makanan lain (Calderone, 2016; Erb and Erb, 2003; Ito, 2009;). Jumlah asupan MSG harian rata-rata diperkirakan hingga $10 \mathrm{gr} / \mathrm{hari}$. Pada kenyataannya jumlah asupan MSG kemungkinan lebih besar lagi karena pada penelitian dahulu belum memperkirakan jumlah MSG yang tersembunyi dalam bahan makanan itu sendiri (He et al., 2011).

Beberapa penelitian menjelaskan adanya efek MSG terhadap organ tubuh manusia seperti otak, ovarium, testis, hepar dan ginjal. Pada dosis rendah MSG menyebabkan peningkatan berat badan yang signifikan, penurunan fungsi kognitif, tetapi tanpa perubahan serum atau tingkat serotonin di otak atau perubahan patologis di otak, juga dapat menyebabkan perubahan degeneratif di otak pada tikus jantan (Abdel et al., 2018). Penelitian terhadap ovarium mencit yang sedang hamil dengan pemberian MSG $4 \mathrm{mg} / \mathrm{grBB}$ didapati gangguan pada ovarium bahwa berkurangnya praimplantasi sekitar 56,43\% (Sufitni et al., 2019). Pemberian MSG dosis tinggi pada hewan membuktikan bahwa MSG dapat menyebabkan nekrosis pada neuron hipotalamus, nukleus arkuata hipotalamus, kemandulan pada jantan dan betina, berkurangnya berat hipofisis, anterior, adrenal, tiroid, uterus, ovarium, dan testis, kerusakan fungsi reproduksi, dan berkurangnya jumlah anak (Wakidi, 2012).

MSG memiliki efek toksik pada testis yang menyebabkan oligozoospermia dan meningkatkan morfologi sperma yang abnormal dengan bergantung dosis yang diberikan pada tikus wistar (Salim dkk, 2017). Konsumsi MSG dalam waktu lama dapat menyebabkan ketidakseimbangan antara antioksidan dan reactive oxygen species (ROS) yang menyebabkan kerusakan sel akibat stress oksidatif. Peningkatan produksi radikal bebas dan terjadinya peroksidasi lipid pada tingkat jaringan di organ testis menyebabkan 
perubahan morfologi spermatozoa yang disertai peningkatan kolesterol testis yang menyebabkan degenerasi sel gonad. Hal ini akan mempengaruhi motilitas spermatozoa sehingga dengan penurunan motilitas spermatozoa yang juga akan mempengaruhi terjadinya proses pembuahan (Sharma and Deshmukh, 2015).

Meningkatnya kadar peroksidasi lipid menyebabkan kerusakan jaringan testis, hal ini paralel dengan penelitian Aitken et al. yang mendapatkan bahwa peningkatan peroksidasi lipid menyebabkan kerusakan oksidatif pada DNA sperma, mengubah fungsi membran, merusak motilitas, dan memiliki efek yang signifikan pada perkembangan spermatozoa. Efek toksik MSG pada parameter fisiologis dan biokimia spermatozoa terkait dengan peningkatan produksi radikal bebas di organ reproduksi (Hamza and Al-Harbi, 2014).

Antioksidan memainkan peran penting dalam perlindungan terhadap peroksidasi lipid yang memiliki efek perlindungan dengan mengurangi atau mencegah kerusakan oksidatif. Antioksidan mencegah reaksi berantai peroksidasi lipid dalam membran seluler dengan mengganggu penyebaran radikal lipid. Antioksidan berperan penting dalam banyak proses biologis yang dapat mengurangi kelainan sel sperma dan motilitas yang disebabkan oleh bahanbahan kimia (Hamza and Al-Harbi, 2014).

Di Indonesia banyak sekali bahanbahan alami yang mempunyai kandungan antioksidan cukup tinggi. Salah satu bahan alami yang banyak dikenal oleh masyarakat adalah semangka. Semangka mengandung lemak, protein dan kalori dalam jumlah rendah, dan juga mengandung banyak vitamin dan mineral, alkaloid, flavonoid, tannin, dan likopen (Sharma and Deshmukh, 2015).

Semangka merupakan salah satu sumber makanan yang kaya akan antioksidan likopen. Asupan satu hingga tiga irisan semangka akan menyediakan antara 6-18 mg likopen dan 0,18-0,54 mmol TEAC (Trolox Equivalent Antioksidan Capacity), yang diduga dapat melindungi dari penyakit-penyakit terkait stress oksidatif (Pinto et al, 2011).

Likopen merupakan hidrokarbon karotenoid alifatik yang sangat dibutuhkan oleh tubuh dan salah satu antioksidan yang sangat kuat kemarnpuannya mengendalikan radikal bebas, dan likopen lebih efisien daripada vitamin E. Konsumsi likopen diyakini dapat meningkatkan kualitas seks, meningkatkan jumlah sperma, memperbaiki struktur sperma dan meningkatkan motilitas sperma sehingga dapat meningkatkan fertilitas pria (Anas dan Asterina, 2011).

Kebutuhan likopen pada saat ini belum ada angka pasti mengenai asupan harian likopen, hal ini tergantung dari populasi yang diteliti. Asupan likopen harian ratarata di Amerika Serikat berkisar 6,6-10,5 $\mathrm{mg}$ /hari untuk pria dan 5,7-10,4 mg/hari untuk wanita. Asupan likopen harian dari berbagai negara yang dilaporkan rata-rata adalah 1,1 mg/hari di Inggris, 1,6 mg/hari di Australia, 4,8 mg/hari di Perancis, 4,9 $\mathrm{mg} /$ hari di Belanda, dan 7,4 mg/hari di Italia. Menurut Rao (2006) asupan harian rata-rata likopen sebanyak 5-10 $\mathrm{mg}$ /hari (Pinto et al, 2011; Rao et al, 2006).

Berdasarkan kajian literatur belum pernah ada penelitian tentang pemberian jus semangka dan perannya terhadap jumlah dan motilitas spermatozoa pada tikus yang dipapari MSG, sehingga penulis ingin mengetahui efek jus semangka terhadap jumlah dan motilitas sperma.

\section{METODE PENELITIAN}

Jenis penelitian ini kuantitatif merupakan penelitian eksperimental dengan desain post test only control group. Penelitian ini menggunakan sampel 35 ekor tikus Wistar jantan dewasa, dengan berat 150-200 gr. Hewan tikus diperoleh dari Laboratorium Farmasi, Universitas Sumatera Utara. Tikus dipelihara dan diuji di Laboratorium Farmakologi dan 
Terapeutik Fakultas kedokteran Universitas Sumatera Utara dengan ruangan yang berventilasi baik pada suhu $22-25^{\circ} \mathrm{C}$ yang menyesuaikan pada lingkungan dan cahaya yang alami. Protokol penelitian telah disetujui oleh Komite Etik Penelitian Hewan Fakultas MIPA Biologi Universitas Sumatera Utara.

Monosodium glutamat (MSG) yang digunakan diperoleh dari toko dengan merek dagang Ajinomoto produksi PT.Ajinomoto Indonesia, bubuk MSG berupa kristal putih mengandung monosodium glutamate murni dan terbungkus rapi dalam kantong plastik.

Tikus dibagi menjadi 5 kelompok secara acak, masing-masing kelompok terdiri dari 7 ekor tikus. Kelompok kontrol negatif $(\mathrm{KN})$ diberi makan pellet dan air minum biasa; Kelompok kontrol positif (KP) diberi perlakuan MSG dengan dosis $10 \mathrm{mg} / \mathrm{gr}$ BB dan air minum biasa; Kelompok perlakuan 1 (P1) diberi MSG dosis $10 \mathrm{mg} / \mathrm{gr}$ BB dan jus semangka 25\%; Kelompok perlakuan 2 (P2) diberi MSG dosis $10 \mathrm{mg} / \mathrm{gr} \mathrm{BB}$ dan jus semangka 50\%; Kelompok perlakuan 3 (P3) diberi MSG dosis $10 \mathrm{mg} / \mathrm{gr} \mathrm{BB}$ dan jus semangka $100 \%$. Semua kelompok diberi perlakuan selama 30 hari.

Tahap pembuatan jus semangka, buah semangka dicuci bersih kemudian dipotong dan dipisahkan bagian putih dan bagian merah buah semangka, selanjutnya timbang bagian merah semangka sebanyak 10.000 gr atau sama dengan 544,32 mg likopen. Jus semangka dibuat dengan cara buah semangka dihaluskan dengan menggunakan blender tanpa ditambahkan air kemudian disaring menggunakan saringan kasar dan halus serta ditekan untuk memisahkan air dengan ampasnya sehingga diperoleh jus semangka $100 \%$. Untuk pembuatan jus semangka $50 \%$ dan $25 \%$ dilakukan pengenceran dengan ditambahkan air pada jus semangka $100 \%$ sebanyak 50\% sehingga didapati jus semangka $50 \%$, selanjutnya jus semangka
$100 \%$ ditambahkan air sebanyak $75 \%$ sehingga didapati jus semangka $25 \%$.

Pemberian MSG dilakukan dengan menggunakan sonde yang diberikan langsung pada kelompok tikus yang mendapat perlakuan MSG. Pemberian MSG dan jus semangka diberikan setiap hari pada kelompok yang mendapat perlakuan tersebut selama 30 hari. Pada hari ke 31 diambil vas deferens tikus Wistar untuk dilakukan pengambilan data jumlah dan motilitas spermatozoa. Vas deferens ditekan dengan perlahan sehingga sekresi cairan vas deferens keluar dan tersuspensi. Sampel yang telah terkumpul terlebih dahulu dihomogenkan, kemudian diambil sebanyak $10 \mu \mathrm{l}$ dan diteteskan ke dalam kotak-kotak hemositometer Improved Neubauer yang telah ditutup dengan kaca penutup. Dibawah mikroskop cahaya pembesaran 400x, hemositometer diletakkan dan dihitung jumlah dan motilitas sperma pada kotak/bidang A, B, C, D, dan E. Hasil perhitungan jumlah spermatozoa kemudian dimasukkan ke dalam rumus penentuan jumlah spermatozoa $/ \mathrm{ml}$ suspensi spermatozoa sebagai berikut.

Jumlah spermatozoa $=\mathrm{N} / 2 \times 10^{5}$ spermatozoa $/ \mathrm{mL}$ supens

$\mathrm{N}=$ jumlah spermatozoa yang dihitung pada kotak A,B,C,D, dan E

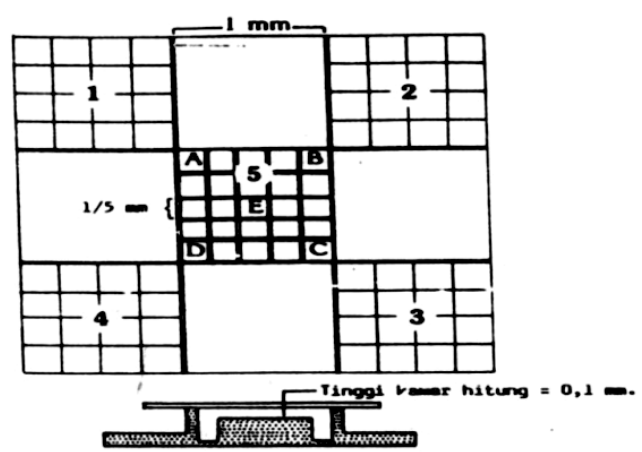

Gambar 1. Hemositometer Improved Neubauer 
Untuk pengamatan terhadap motilitas dilakukan dengan cara mengamati gerakan spermatozoa dan dikategorikan menjadi dua yaitu sel spermatozoa motil (bergerak) dan non motil (tidak bergerak). Dilakukan pengamatan pada empat sampai enam lapangan pandang yang harus diperiksa untuk mendapat 100 spermatozoa secara berurutan yang kemudian diklasifikasi sehingga menghasilkan persentase setiap kategori motilitas.

Data yang dikumpulkan adalah data kuantitatif berupa perhitungan jumlah dan motilitas spermatozoa didalam vas deferens. Untuk mengetahui ada tidaknya pengaruh perlakuan terhadap parameter yang diukur, dilakukan uji statistik non parametrik menggunakan Mann-Whitney dengan nilai $\alpha 0.05$.

\section{HASIL DAN PEMBAHASAN}

Jumlah sel spermatozoa tikus Wistar yang diberikan MSG dan diberi jus semangka adalah sebagai berikut:

Tabel 1. Rata-rata jumlah dan motilitas

\begin{tabular}{cccc}
\multicolumn{4}{c}{ Sperma tikus } \\
\hline $\begin{array}{c}\text { Kelom } \\
\text { pok }\end{array}$ & $\begin{array}{c}\text { Jumlah } \\
\text { Spermato } \\
\text { zoa } \\
\text { (juta/mL) }\end{array}$ & $\begin{array}{c}\text { Motilitas Spermatozoa } \\
(\%)\end{array}$ \\
\cline { 3 - 4 } & & Bergerak & $\begin{array}{c}\text { Tidak } \\
\text { Bergerak }\end{array}$ \\
& & & \\
\hline KN & $24,14 \pm$ & $73.43 \pm$ & $26.57 \pm$ \\
& 3,26 & 11.07 & 11.07 \\
KP & $11,86 \pm$ & $36.71 \pm$ & $63.29 \pm$ \\
& 7,83 & 18.26 & 18.26 \\
P1 & $8,50 \pm$ & $27.57 \pm$ & $72.43 \pm$ \\
& 3,06 & 10.53 & 10.53 \\
P2 & $11,36 \pm$ & $45.43 \pm$ & $54.57 \pm$ \\
& 2,48 & 12.53 & 12.53 \\
P3 & $10,29 \pm$ & $56.14 \pm$ & $43.86 \pm$ \\
& 3,99 & 8.59 & 8.59 \\
\hline
\end{tabular}

Nilai rata-rata jumlah spermatozoa dari yang terbesar sampai yang terkecil secara berturut-turut adalah pada kelompok $\mathrm{KN}$, KP, P2, P3, dan P1. Jumlah spermatozoa pada kelompok KP mengalami penurunan dibandingkan dengan kelompok KN. Nilai rata-rata motilitas spermatozoa dari yang terbesar sampai yang terkecil secara berturut-turut adalah pada kelompok $\mathrm{KN}$, P3, P2, KP, dan P1. Motilitas spermatozoa pada kelompok KP mengalami penurunan dibandingkan dengan kelompok KN, P2, dan P3. Pada kelompok perlakuan yang diberikan jus semangka mengalami peningkatan secara berturut-turut yaitu kelompok P1, P2, dan P3.

Analisis secara statistik dilakukan untuk mengetahui kebermaknaan antara kelompok-kelompok tersebut. Sebelumnya dilakukan uji normalitas sebaran data. Dari uji tersebut diketahui bahwa sebaran data tidak berdistribusi normal. Kemudian dilakukan uji Mann Whitney dan diperoleh nilai $p$ value $<0,05$ yang menunjukkan bahwa terdapat perbedaan bermakna antara semua kelompok. Hasilnya dapat dilihat pada Tabel 2.

Tabel 2. Perbandingan jumlah dan motilitas spermatozoa pada berbagai

\begin{tabular}{ccc}
\multicolumn{3}{c}{ kelompok } \\
Kelompok & \multicolumn{2}{c}{ Signifikansi } \\
\cline { 2 - 3 } & $\mathrm{p}=0.009^{*}$ & $\mathrm{p}=0.003^{*}$ \\
\hline KN vs KP & $\mathrm{p}=0.002^{*}$ & $\mathrm{p}=0.002^{*}$ \\
KN vs P1 & $\mathrm{p}=0.002^{*}$ & $\mathrm{p}=0.005^{*}$ \\
KN vs P2 & $\mathrm{p}=0.002^{*}$ & $\mathrm{p}=0.011^{*}$ \\
KN vs P3 & $\mathrm{p}=0.608^{* *}$ & $\mathrm{p}=0.221^{*}$ \\
KP vs P1 & $\mathrm{p}=0.748^{* *}$ & $\mathrm{p}=0.748^{* *}$ \\
KP vs P2 & $\mathrm{p}=0.949^{* *}$ & $\mathrm{p}=0.040^{*}$ \\
KP vs P3 & $\mathrm{p}=0.123^{* *}$ & $\mathrm{p}=0.015^{*}$ \\
P1 vs P2 & $\mathrm{p}=0.607^{* *}$ & $\mathrm{p}=0.002^{*}$ \\
P1 vs P3 & $\mathrm{p}=0.438^{* *}$ & $\mathrm{p}=0.095^{* *}$ \\
P2 vs P3 &
\end{tabular}

Keterangan:

* (significant): terdapat perbedaan yang bermakna secara statistik $(\mathrm{p}<0.05)$

** (non-significant): tidak ada perbedaan yang bermakna secara statistik $(\mathrm{p}>0.05)$

Pada tabel 2 dapat dilihat bahwa kelompok kontrol positif (KP), P1, P2, dan P3 yang diberikan MSG mengalami penurunan jumlah dan motilitas spermatozoa secara bermakna dibandingkan dengan kelompok kontrol negatif $(\mathrm{KN})$. Pada kelompok P3 yang 
diberikan jus semangka mengalami peningkatan motilitas secara bermakna dibandingkan kelompok KP.

Hasil penelitian menunjukkan bahwa terdapat penurunan jumlah dan motilitas spermatozoa pada kelompok KP, P1, P2, dan P3 atau kelompok yang dipapar dengan MSG dibandingkan dengan kelompok $\mathrm{KN}$ atau kelompok tanpa dipapar dengan MSG. Pemberian MSG dapat menyebabkan terjadinya peningkatan kadar $\mathrm{Ca} 2+$ dalam intrasel leydig, peningkatan $\mathrm{Ca} 2+$ akan menyebabkan gangguan pada mitokondria dan mengaktifkan enzim ATPase, phospholipases, endonuklease, dan protease sehingga terjadinya gangguan pada sintesis ATP dan gangguan pada permeabilitas membran sel sehingga pada akhirnya akan menyebabkan kematian pada sel leydig dan sel sperma (Tawfik and Al-Badr, 2012; Salim et al, 2017).

Diketahui bahwa MSG menghasilkan reactive oxygen species (ROS) (Hamza and Al-Harbi, 2014). ROS sangat mudah menyebabkan kerusakan pada spermatozoa karena membran selnya mengandung sejumlah besar asam lemak tidak jenuh (PUFA) sehingga mudah teroksidasi (peroksidasi lipid) dan sitoplasmanya hanya mengandung sedikit enzim antioksidan yang dapat menetralisir ROS (Walczak-Jedrzejowska et al., 2013). ROS juga dapat merusak integritas DNA pada nukleus spermatozoa sehingga akan menginduksi terjadinya apoptosis sel yang pada akhirnya menyebabkan penurunan jumlah dan motilitas spermatozoa (Quratul'ainy, 2006).

Motilitas spermatozoa dari kelompok perlakuan yang diberikan jus semangka menunjukkan adanya peningkatan dibandingkan dengan kelompok kontrol positif. Peningkatan motilitas spermatozoa terjadi karena tikus diberi perlakuan berupa jus semangka yang berfungsi sebagai antioksidan dan diharapkan dapat mengurangi kerusakan akibat radikal bebas yang berlebihan tersebut. Kandungan likopen dalam semangka memiliki kekuatan antioksidan yang lebih baik daripada vitamin $\mathrm{C}$ dan E (Bagiada et al, 2005). Likopen sebagai antioksidan mempunyai kemampuan untuk mencegah kerusakan sel-sel tubuh akibat radikal bebas dengan mengurangi efek toksik dari ROS (Sulistyowati, 2006).

Likopen dapat meningkatkan kualitas jumlah sperma, memperbaiki struktur sperma dan meningkatkan motilitas sperma, hal ini diperkuat dengan penelitian yang dilakukan pada pria infertil di India yang hasilnya menyatakan bahwa pria yang mengkonsumsi makanan yang kaya likopen dengan kadar likopen 20 mg, 2 kali dalam sehari selama 3 bulan berturut-turut akan meningkatkan jumlah sperma sekitar $67 \%$, struktur sperma akan mengalami perbaikan sebanyak $63 \%$ dan motilitas sperma meningkat sebesar 73\% (Anas dan Asterina, 2011; Gupta and Kumar, 2002).

Hasil perhitungan rata-rata motilitas dari data yang didapat bahwa pada kelompok P1, P2, dan P3 yang diberikan jus semangka didapati rata-rata motilitas spermatozoa yang semakin mendekati kelompok KN. Hasil hitung menunjukkan bahwa konsentrasi jus semangka 100\% memberikan efek paling baik yang diikuti konsentrasi $50 \%$.

\section{SIMPULAN}

Pemberian MSG $10 \quad \mathrm{mg} / \mathrm{grBB}$ menunjukkan hasil yang bermakna terhadap jumlah $(p$ value $=0.009)$ dan motilitas ( $p$ value $=0.003$ ) spermatozoa. Pemberian jus semangka dapat memperbaiki jumlah dan motilitas sperma tikus yang dipapar dengan MSG, namun berdasarkan uji statistik tidak bermakna pada jumlah $(\mathrm{p}$ value $=0.608)$ dan motilitas ( $p$ value $=0.221$ )

Perlu dilakukan penelitian lanjutan terhadap jus semangka dengan meningkatkan konsentrasi pemberian jus semangka. Perlunya dilakukan pemeriksaan tambahan seperti pemeriksaan hormon $\mathrm{FSH}$, LH, Testosteron, dan Gonadotropin Releasing Hormone (GnRH). 


\section{DAFTAR PUSTAKA}

Abdel Moneim, WM. et al. (2018). Monosodium Glutamate Affects Cognitive Functions In Male Albino Rats. Egypt J Forensic Sci, p.8-9.

Albrahim, T. (2018). Roles of Moringa oleifera Leaf Extract in Improving the Impact of High Dietary Intake of Monosodium GlutamateInduced Liver Toxicity, Oxidative Stress, Genotoxicity, DNA Damage, and PCNA Alterations in Male Rats. Oxid Med Cell Longev; 1-11.

Anas E. dan Asterina. (2011). Efek Pemberian Jus Tomat (Lycopersicum pyriporme) Terhadap Spermatogenesis pada Tikus Putih (Rattus norvegicus) Jantan Dewasa Hyperkolesterolemia. $M K A$. No.1 Vol.35.

Bagiada A., Arcana, Mahasucipta. (2005). Peran Antioksida Untuk Mencegah Beberapa Kelainan Jaringan Tubuh. MKI; 55(6):455-8.

Calderone L. (2016). Here's how food companies sneak MSG into foods. https://www.businessinsider.com/ msg-goes-by-many-differentnames-2016-1/?IR=T (accessed May 12, 2019)

Erb JE, Erb TM. (2003). The slow poisoning of America. Virginia Beach: VA Paladins Press.

Ghosh, S.K. (2017). Studies on Monosodium L-Glutamate (MSG): Harmful Effects of Prolonged and High Dose Administration of MSG on Animal Body. WJPPS; 6(4), 500-503.

Gupta NP., Kumar R. (2002). Lycopene Therapy in Idiopathic Male Infertility-a Preliminary Report. Int Urol Nephrol; 34(3): 369-372.

Hamza R.Z. and AL-Harbi M.S. (2014). Monosodium Glutamate Induced Testicular Toxicity and the
Possible Ameliorative Role of Vitamin E or Selenium in Male Rats. Toxicol Rep 1. 1037-1045.

He K., Du S., Xun P., Sharma S., Wang H., Zhai F., and Popkin B. (2011). Consumption of monosodium glutamate in relation to incidence of overweight in Chinese adults: China Health and Nutrition Survey (CHNS). Am J Clin Nutr; 93(6):1328-36.

Ito M. (2009). Domestic and overseas food products business FY 2008-2010 medium term plan. Available from: http://www.ajinomoto.com/ir/pdf/ 08July02-food-E.pdf

Pinto, MP., et al. (2011). Lycopene Content and Antioxidant Capacity of Portuguese Watermelon Fruits. EJEAFChe, 10(4), p.2090-2097.

Quratul'ainy. (2006). Pengaruh Pemberian Vitamin E Terhadap Jumlah Spermatozoa Mencit Jantan strain Babl/c yang Diberi Paparan Asap Rokok. [Skripsi]. Semarang: Fakultas Kedokteran Universitas Diponegoro.

Rao AV., Ray MR., and Rao LG. 2006. Lycopene. Adv Food Nutr Res. Vol.51:99-164.

Salim L. dkk. (2017). Pengaruh Penghentian Monosodium Glutamat terhadap Jumlah Sel Leydig Tikus Putih (Rattus norvegicus) Jantan Dewasa. $J$ Cereb, Vol. 3 No.3.

Sharma V, Deshmukh R. (2015). Ajimomoto (MSG): A Fifth Taste Or A Bio Bomb. EJPMR. (2)2 : 381-400.

Sufitni, Feriyawati L., Pane YS., Lelo A. (2019). The Effect of Torbangun Leaves Tea on MSG-Induced Fetal Development Disorder in Mice. SUMEJ, 2(1), 34-38.

Sulistyowati Y. (2006). Pengaruh Pemberian Likopen Terhadap Status Antioksidan (Vitamin C, vitamin $\mathrm{E}$ dan Gluthathion Peroksidase) Tikus (Rattus 
norvegicus galur Sprague Dawley) Hiperkolesterolemik. [Thesis]. Semarang: Program Studi Magister Ilmu Biomedik.

Tawfik M.S. and Al-Badr N. (2012). Adverse Effects of Monosodium Glutamate on Liver and Kidney Functions in Adult Rats and Potential Protective Effect of Vitamins $\mathrm{C}$ and E. Food and Nutrition Sciences, 3, 651-659.

Wakidi, R.F. (2012). Efek Protektif Vitamin C dan E Terhadap Mutu Sperma Mencit Jantan Dewasa yang di Pajan dengan Monosodium Glutamat. Tesis. Medan: Fakultas Farmasi Universitas Sumatera Utara.

Walczak-Jedrzejowska R., Wolski JK., Slowikowska-Hilczer J. (2013). The Role of Oxidative Stress and Antioxidants in Male Fertility. Cent European J Urol, 66(1): 6067.

Yonata, A. dan Iswara, I. (2016). Efek Toksik Konsumsi Monosodium Glutamate Toxic Effects Consumption of Monosodium Glutamate. J Majority; 2: 1-5. 